\title{
Case of migrated Gore-Tex implant following external thyroplasty
}

\author{
Joel Hardman, ${ }^{1}$ Malcolm A Buchanan, ${ }^{2}$ Faruque Riffat ${ }^{2}$
}

${ }^{1}$ Sydney Medical School, University of Sydney, Sydney, New South Wales, Australia ${ }^{2}$ Westmead Hospital, Westmead, New South Wales, Australia

\section{Correspondence to} Dr Joel Hardman, jt.hardman86@gmail.com

Accepted 25 May 2016
CrossMark

To cite: Hardman J Buchanan MA, Riffat F. BMJ Case Rep Published online: [please include Day Month Year] doi:10.1136/bcr-2016215277

\section{DESCRIPTION}

Gore-Tex is a commonly used material for external thyroplasty in patients with unilateral vocal cord palsy. ${ }^{1}$ It medialises the paralysed cord to enable the normal contralateral cord to appose with it in the midline, thereby improving voice quality and preventing aspiration.

Potential complications from its use, although rare, include extrusion and chronic inflammation at the site of insertion, with evidence of foreign body giant cell reaction.

We present a case of a patient presenting with shortness of breath and worsening voice quality. The patient had suffered a right vocal cord palsy following thyroidectomy. The patient subsequently underwent gel foam injections followed by a Gore-Tex medialisation thyroplasty. Nasendoscopy demonstrated exuberant right false cord granulation (figure 1).

The decision was made to remove the Gore-Tex, and an attempt was made through a standard external thyroplasty approach, although this was unsuccessful as the implant could not be located. A repeat CT was organised with high-resolution laryngeal reconstructions (figure 2), which demonstrated the implant spiralling into a position more superiorly than expected. At re-exploration, the glottis was approached from the superior edge of the thyroid ala with dissection of the mucosa. The implant was located in the right false vocal cord and removed without further complication.

Extrusion of Gore-Tex implants, though uncommon, has been documented; and with migration to other laryngeal sub sites, it is even less common. Extruded implants are more obvious and can be

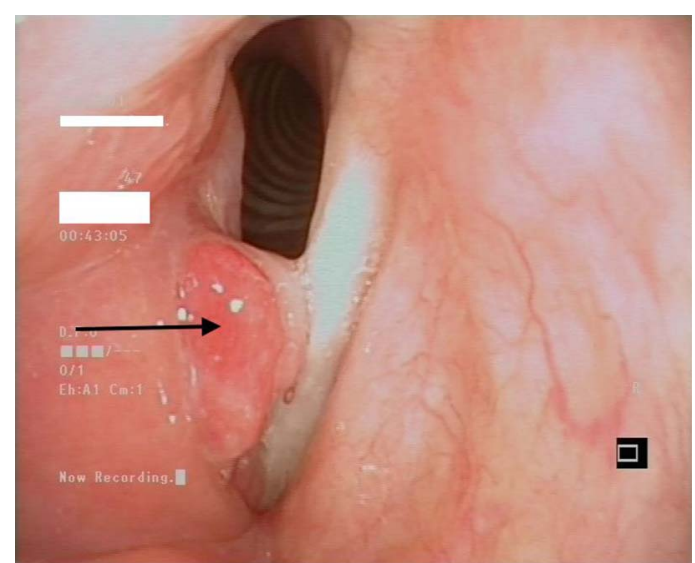

Figure 1 Flexible nasendoscopic view of the glottis. Arrow indicating granulation tissue arising from the right vocal cord.

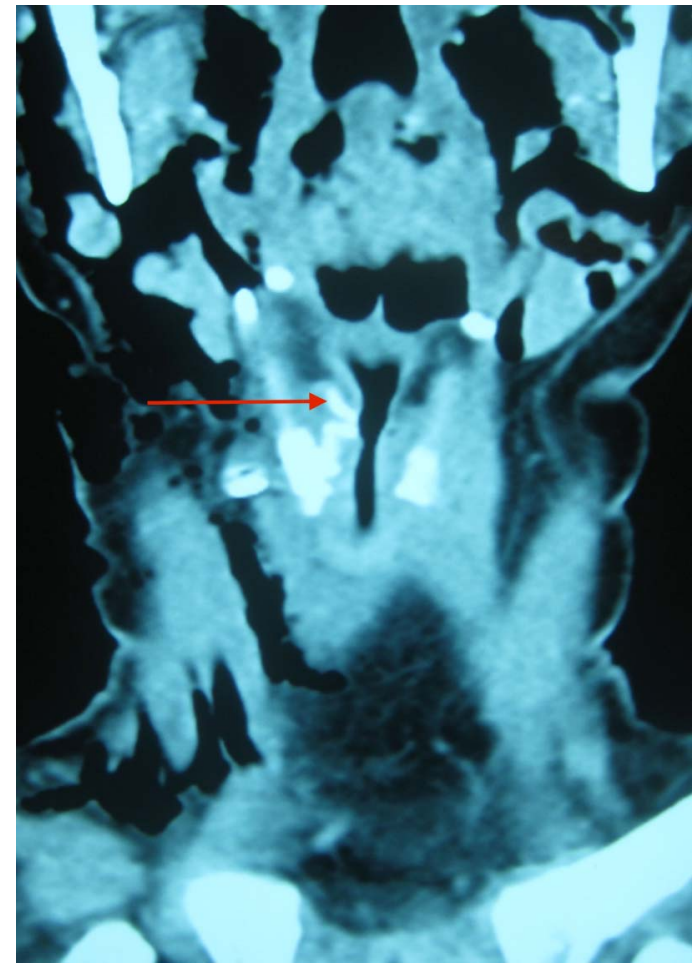

Figure 2 CT scan (coronal view) of the neck, demonstrating high-density material (arrow) in the right supra-glottic space, which at surgery was confirmed to be the Gore-Tex implant.

managed endoscopically. ${ }^{2}$ This case also demonstrates the value of high-resolution CT scans with laryngeal reconstructions as part of preoperative planning. Standard thyroplasty approaches may not be sufficient to retrieve migrated implants. Dissecting the laryngeal mucosa off the thyroid cartilage from superior to inferior is a good technique for accessing superiorly migrated implants.

\section{Learning points}

- Migration of a Gore-Tex implant to another sub site within the larynx is possible.

- High-resolution CT scans with laryngeal reconstructions are useful for preoperative planning.

- Approaching the larynx superiorly over the thyroid cartilage is a successful technique to remove migrated implants. 
Contributors $\mathrm{JH}$ prepared the manuscript for submission. MAB acquired the clinical photos and reviewed the manuscript. FR was the consultant surgeon.

Competing interests None declared.

Patient consent Obtained.

Provenance and peer review Not commissioned; externally peer reviewed.

\section{REFERENCES}

1 Misono S, Merati AL. Evidence-based practice: evaluation and management of unilateral vocal fold paralysis. Otolaryngol Clin North Am 2012; 45:1083-108.

2 Halum SL, Postma GN, Koufman JA. Endoscopic management of extruding medialization laryngoplasty implants. Laryngoscope 2005;115:1051-4.

Copyright 2016 BMJ Publishing Group. All rights reserved. For permission to reuse any of this content visit http://group.bmj.com/group/rights-licensing/permissions.

BMJ Case Report Fellows may re-use this article for personal use and teaching without any further permission.

Become a Fellow of BMJ Case Reports today and you can:

- Submit as many cases as you like

- Enjoy fast sympathetic peer review and rapid publication of accepted articles

- Access all the published articles

- Re-use any of the published material for personal use and teaching without further permission

For information on Institutional Fellowships contact consortiasales@bmjgroup.com

Visit casereports.bmj.com for more articles like this and to become a Fellow 